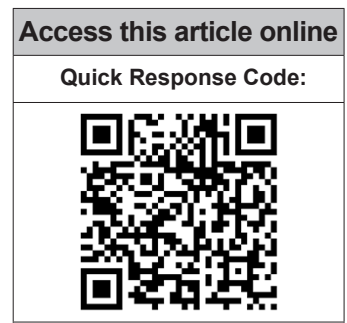

Website:

www.jponline.org

DOI:

10.4103/JLP.JLP_6_19
Departments of Clinical Virology, ${ }^{1}$ Critical Care and Anaesthesia, ${ }^{2}$ Pulmonary Medicine and ${ }^{3}$ Hepatology, Institute of Liver and Biliary Sciences,

Departments of ${ }^{4}$ Trauma and Critical Intensive

Care Unit, and ${ }^{5}$ Surgery, JPNATC, All India Institute of Medical Sciences, New Delhi, India

Address for correspondence:

Dr. Ekta Gupta, Department of Clinical Virology, Institute of Liver and Biliary

Sciences, D-1, Vasant Kunj, New Delhi, India. E-mail: ektagaurisha@ gmail.com

Submission: 12-01-2019 Revised: 02-04-2019

\title{
Spectrum of respiratory viral infections in liver disease patients with cirrhosis admitted in critical care unit
}

\author{
Vijeta Bajpai, Ekta Gupta, Lalita Gauri Mitra'1, Hemant Kumar², Rakhi Maiwall², \\ Kapil Dev Soni ${ }^{4}$, Amit Gupta ${ }^{5}$
}

\section{Abstract:}

BACKGROUND: Clinical significance of respiratory viruses (RVs) as an etiology of pneumonia in liver disease patients with cirrhosis is usually underestimated. Therefore, the aim of this study was to evaluate the spectrum of RVs in cirrhotic patients with pneumonia admitted in critical care units (CCUs) and its impact on the clinical outcome of cirrhotic patients.

MATERIAL AND METHOD: A prospective study was conducted in a tertiary care CCU, and consecutive cirrhotic patients with pneumonia were included. Bronchoalveolar lavage or throat swab/nasal swab was collected in viral transport medium for analysis of RVs by multiplex real-time polymerase chain reaction. A total of 135 cirrhotic patients were included, viral and bacterial etiology of pneumonia was identified, and analysis was done with the clinical outcome.

RESULTS: Overall, RVs were detected in 30 (22.2\%) cirrhotic patients and viral-bacterial coinfection in $16(11.8 \%)$ cirrhotic patients. The most common virus detected was rhinovirus in $9(30 \%)$ patients. Mortality in cirrhotic patients with RV infection was significantly higher in comparison to cirrhotic patients with no RV infection (25 [83.3\%] and 11 [12.3\%], respectively, $P<0.001$ ).

CONCLUSION: Respiratory viruses in cirrhotic patients with pneumonia are associated with poor clinical outcome.

Key words:

Care, chronic liver disease, critical, pneumonia, respiratory virus, unit, viral-bacterial coinfection

\section{Introduction}

Tnfectious diseases are common in liver disease patients with cirrhosis and exert one of the most important reasons for morbidity and mortality in critical care units (CCUs). Pneumonia is one of the most common infections in liver disease patients with cirrhosis admitted in CCU..$^{[1,2]}$ The prevalence of pneumonia is reported in about $21.4 \%$ of cirrhotic patients with mortality rates as high as $37 \%-41 \% .{ }^{[3]}$ There are several consequences of pneumonia in cirrhotic patients which include acute on chronic liver failure, multiple organ

This is an open access journal, and articles are distributed under the terms of the Creative Commons Attribution-NonCommercial-ShareAlike 4.0 License, which allows others to remix, tweak, and build upon the work non-commercially, as long as appropriate credit is given and the new creations are licensed under the identical terms.

For reprints contact: reprints@medknow.com failure, sepsis, prolonged hospitalization, and mortality. ${ }^{[4]}$ Although pneumonia exhibits higher mortality in patients with cirrhosis, majority of the studies focused on bacterial pneumonia as the most common cause of pneumonia in cirrhotic patients; other pathogens especially are usually underestimated in such patients and are often not underreported. ${ }^{[5,6]}$ There are very few studies which have shown the influence of respiratory viruses (RVs) in clinical outcome of cirrhotic patients in CCU. ${ }^{[7-9]}$ Till now, there is no published study showing the prevalence of RVs and their bacterial coinfections in cirrhotic patients admitted in CCU care. With this background, the purpose of the current study is to investigate

\footnotetext{
How to cite this article: Bajpai V, Gupta E, Mitra LG, Kumar H, Maiwall R, Soni KD, et al. Spectrum of respiratory viral infectionsin liver disease patients with cirrhosis admitted in critical care unit. J Lab Physicians 2019;11:356-60.
} 
the prevalence of RVs in cirrhotic patients with pneumonia and its impact on the clinical outcome of cirrhotic patients with pneumonia admitted in CCUs.

\section{Material and Methods}

This is a prospective study, done over a period of 1 year from January 2016 to December 2016, in CCUs in liver center, and All consecutive cirrhotic patients who had developed clinical signs and symptoms of pneumonia were included. Pneumonia was defined as a new infiltrate focus on chest radiological examination and one or more symptoms as follows: respiratory symptoms (i.e. cough, chest pain, and dyspnea), sign of infection (fever $>38^{\circ} \mathrm{C}$, and/or white blood cell count $>12,000 / \mathrm{mm}^{3}$ or $<4000 / \mathrm{mm}^{3}$. ${ }^{[10]}$ The exclusion criteria included: (1) under 18 years; (2) pregnancy; (3) patients with immunosuppression (including patients with chemotherapy and radiotherapy and patients with drug-induced immunosuppression as a result of cytotoxic or corticosteroids [defined as $>1 \mathrm{mg} / \mathrm{kg}$ prednisone for $>1$ month]); (4) bone marrow or solid organ transplantation; (5) patients with hepatocellular carcinoma or with other types of carcinoma; and (6) HIV infection. Bronchoalveolar lavage (BAL) or throat swab / nasal swab (TS/NS) was collected from cirrhotic patients with pneumonia. BAL sample was collected by trained pulmonologist patients on mechanical ventilator because the TS/NS could not be from them. TS and NS were collected from nonventilated patients with pneumonia. All samples were transported in viral transport media immediately to the virology laboratory on ice. All the samples were stored at $-80^{\circ} \mathrm{C}$ till further processing. Complete clinical characteristics of the patient and other biochemical parameters were recorded from the hospital information system. The study was approved by the ethical committee (IRB Reference No: F.25/5/81/ILBS/ AC/2015/9601) of the institute.

\section{Clinical definitions}

A patient admitted to the intensive care unit (ICU) with the diagnosis of pneumonia without prior contact of health settings was considered as having community-acquired pneumonia (CAP).Infection in a patient who developed clinical features of pneumonia after $48 \mathrm{~h}$ of admission was considered as hospital-acquired pneumonia (HAP). Impact of clinical outcome due to viral pneumonia was assessed if there was a requirement for either invasive mechanical ventilation, extended duration of stay in ICU (>7 days), or mortality of patients.

Multiplex quantitative real-time polymerase chain reaction for respiratory viruses

In all the samples, nucleic acids (DNA/RNA) were extracted using commercial kit (RTP DNA/RNA Virus Mini Kit, Stratec Molecular, Birkenfeld, Germany) according to the manufacturer's instructions. Multiplex quantitative real-time polymerase chain reaction was done using commercially available kit capable of detection and quantification of 33 different pathogens (21 viruses and 12 bacteria; FTD-RP33, Fast-Track Diagnostics, Luxembourg) as per the manufacturer's protocol [Table 1]. Results were expressed as copies/ $\mathrm{ml}$, and the linear range of the assay is $10^{2}-10^{9}$ copies/ $\mathrm{ml}$. Data were presented as mean \pm standard deviation or an absolute number and percentage. To compare categorical variables, Chi-square test was used, and for continuous variables, Student's $t$-test was used. $P<$ 0.05 was considered statistically significant. Data were recorded and analyzed using SPSS (version 21.0; SPSS). (IBM, Armonk, NY, United States of America).

\section{Results}

A total of 1076 liver disease patients with cirrhosis were admitted in ICU during the study period. Diagnosis of pneumonia was made in 135 (11.2\%) cirrhotic patients. Eighty-six (64.4\%) patients had HAP and 49 (36.3\%) patients had CAP. The baseline characteristics of the study population are depicted in Table 2. A total of 88 patients $(65.1 \%)$ underwent bronchoscopy BAL for etiologic diagnosis of pneumonia, and TS/NSs were collected from 47 (34.9\%) patients. Figure 1 shows the workflow and distribution of respiratory pathogens in all patients.

The overall prevalence of RVs was found in 30 (22.2\%) cirrhotic patients with pneumonia, and both viral and bacterial coinfections were seen in $16(11.8 \%)$ cirrhotic patients with pneumonia. The proportion of RV infections were little higher in HAP group than in the CAP group though not significant (17 [56.7\%] and 13 [43.3\%], respectively, $\mathrm{P}=0.47)$. The comparison of various parameters of cirrhotic patients with and without RV infection is shown in Table 3. Overall, rhinovirus ( $\mathrm{RhV}$ ) was the most common identified virus in $9(6.0 \%)$ cirrhotic patients, followed by influenza A (Flu A) in $5(3.7 \%)$ patients, human coronavirus (HCoV) in $3(2.2 \%)$ patients, respiratory syncytial virus (RSV) in $3(2.2 \%)$ patients, human parainfluenza virus (HPIV) in $2(1.4 \%)$ patients, and human metapneumovirus and human adenovirus (HAdV) in one each of the patients. Dual viral infections such as HAdV + HPIV, $\mathrm{HCoV}+\mathrm{RSV}$, and HAdV + RhV were found in one each of the patients, respectively [Table 4]. The seasonal distribution of various RVs is described in Figure 2. RhV was present throughout the year. Flu A virus and RSV were mainly present in winter months. $\mathrm{HCoV}, \mathrm{HAdV}$, and HPIV were mainly present in summer and early winter seasons. Overall, mortality was seen in $50(37.0 \%)$ cirrhotic patients with pneumonia in ICU. Mortality in cirrhotic patients with RV infection was higher than patients with viral-bacterial coinfection (25 [83.3\%] 
Table 1: List of respiratory pathogens identified by an available commercial kit

\begin{tabular}{|c|c|}
\hline Respiratory virus & $\begin{array}{l}\text { Respiratory bacteria/other } \\
\text { respiratory pathogens }\end{array}$ \\
\hline Influenza A & Staphylococcus aureus \\
\hline Influenza B & Chlamydia pneumoniae \\
\hline Influenza C & Haemophilus influenzae $B$ \\
\hline Influenza A (H1N1) pdm 09 & Streptococcus pneumoniae \\
\hline Parainfluenza virus 1 & Klebsiella pneumoniae \\
\hline Parainfluenza virus 2 & Legionella pneumophila \\
\hline Parainfluenza virus 3 & Pneumocystis carinii pneumoniae* \\
\hline Parainfluenza virus 4 & Salmonella species \\
\hline Coronavirus NL63 & Moraxella catarrhalis \\
\hline Coronavirus 229E & Bordetella pertussis \\
\hline Coronavirus OC43 & Haemophilus influenzae \\
\hline Coronavirus HKU1 & Mycoplasma pneumoniae \\
\hline \multicolumn{2}{|l|}{ Human metapneumovirus } \\
\hline \multicolumn{2}{|l|}{ Rhinovirus } \\
\hline \multicolumn{2}{|l|}{ Respiratory syncytial virus } \\
\hline \multicolumn{2}{|l|}{ Adenovirus } \\
\hline \multicolumn{2}{|l|}{ Enterovirus } \\
\hline \multicolumn{2}{|l|}{ Parechovirus } \\
\hline Bocavirus & \\
\hline
\end{tabular}

Table 2: Baseline characteristics of the study population

\begin{tabular}{|c|c|}
\hline Baseline parameters & Total number of patients $(n=135)$ \\
\hline Mean age $\pm S D$ (years) & $48.4 \pm 13.1$ \\
\hline Male (\%) & $112(83.3)$ \\
\hline $\begin{array}{l}\text { Mean leukocyte count } \pm S D \\
\text { cubic/mm } \mathrm{mm}^{3}\end{array}$ & $13.9 \pm 8.9$ \\
\hline Normal range cubic $/ \mathrm{mm}^{3}$ & $4-11$ \\
\hline $\begin{array}{l}\text { Length of hospital stay, median } \\
\text { (IQR) days }\end{array}$ & $11(2-32)$ \\
\hline Mean CTP score \pm SD & $11.75 \pm 2.0$ \\
\hline Mean MELD score $\pm S D$ & $29 \pm 7.4$ \\
\hline \multicolumn{2}{|l|}{ Underlying etiology, $n(\%)$} \\
\hline $\begin{array}{l}\text { Ethanol-related chronic liver } \\
\text { disease }\end{array}$ & $95(70.3)$ \\
\hline Autoimmune liver disease & $15(11.6)$ \\
\hline $\begin{array}{l}\text { Chronic hepatitis B-related } \\
\text { liver disease }\end{array}$ & $26(19.3)$ \\
\hline $\begin{array}{l}\text { Chronic hepatitis C-related } \\
\text { liver disease }\end{array}$ & $9(6.7)$ \\
\hline
\end{tabular}

$\mathrm{SD}=$ Standard deviation, IQR=Interquartile range, $\mathrm{CTP}=\mathrm{Child}-$ Turcotte-Pugh, MELD=Model for End-Stage Liver Disease and 7 [43.3\%], respectively), but the difference was not significant $(P=0.12)$. The difference of mortality of patients with RV infection versus patients without RV infection was significant (25 [83.3\%] and 11 [12.3\%], $\mathrm{P}<0.001$, respectively). The patients with the median ICU stay of cirrhotic patients with pneumonia were 11 days (interquartile range [IQR]: 2-23 days). There was no significant difference in median length of stay of patients in viral infections and viral-bacterial coinfection (9.0 [IQR: 2-30] and 10 [IQR: 5-32] days, respectively). The patients without viral infections had a shorter duration of stay CCUs, 5.0 (IQR:2-23) da.

\section{Discussion}

To the best of our knowledge, this is the first prospective study representing the investigation of viral pneumonia in cirrhotic patients in CCUs. In the present study, we evaluated the epidemiology, clinical characteristics, and prognosis of cirrhotic patients with viral pneumonia in CCUs. Specimens obtained from the upper airway as TS/NS are often used for RV testing in pneumonia patients due to ease of specimen collection in comparison to bronchoscopy collected BAL sample. ${ }^{[11]}$ However, in the current study, the proportion of RVs detected from BAL samples were more than TS/NS though not significant. Therefore, here comes the importance to perform bronchoscopy and collection of BAL sample in the most affected lung segment according to the radiographic signs to recover the responsible respiratory pathogen in patients with pneumonia, especially in patients having chronic liver disease. Over the past decade, several studies have consistently demonstrated RVs to be the second most common etiological factor of CAP, accounting for $13 \%-50 \%$ of diagnosed cases of pneumonia in noncirrhotic patients in CCUs. ${ }^{[2]}$ Our study has demonstrated that the proportion of RV infections was little higher in the HCAP group than in the CAP group in cirrhotic patients, which is similar to one recent study done in nonliver adult patients. ${ }^{[12,13]} \mathrm{A}$ high index of suspicion of viral pneumonia is always necessary in patients with cirrhosis because there are no distinctive clinical features to differentiate between viral and

Table 3: Comparison of various parameters of cirrhotic patients with and without respiratory viruses infection

\begin{tabular}{|c|c|c|c|c|}
\hline Parameters & Patients with RV infection ( $n=30), n(\%)$ & Patients without RV infection ( $n=89), n(\%)$ & OR $(95 \% \mathrm{Cl})$ & $P$ \\
\hline Age $>65$ years & $4(13.3)$ & $12(11.4)$ & $0.875(0.2576-2.8519)$ & 0.8016 \\
\hline Male gender & $27(90)$ & $85(95.5)$ & $0.8995(0.4969-1.6282)$ & 0.7264 \\
\hline CAP & $13(43.3)$ & $25(28.08)$ & $0.549(0.25-1.20)$ & 0.1341 \\
\hline HAP & $17(56.6)$ & $60(67.4)$ & $1.0084(0.5138-1.9791)$ & 0.9806 \\
\hline BAL sample & $22(73.3)$ & $68(76.4)$ & $0.88(0.47-1.65)$ & 0.69 \\
\hline $\begin{array}{l}\text { Mechanical } \\
\text { ventilation } \\
\text { requirement }\end{array}$ & $22(73.3)$ & $68(76.4)$ & $0.88(0.47-1.65)$ & 0.69 \\
\hline Mortality & $25(83.3)$ & $11(12.35)$ & $0.12(0.05-0.28)$ & $<0.001$ \\
\hline
\end{tabular}

$\mathrm{RVs}=$ Respiratory viruses, $\mathrm{OR}=\mathrm{Odds}$ ratio, $\mathrm{Cl}=$ Confidence interval, $\mathrm{CAP}=\mathrm{Community}$-acquired pneumonia, $\mathrm{HAP}=\mathrm{Hospital}$-acquired pneumonia,

$\mathrm{BAL}=$ Bronchoalveolar lavage 


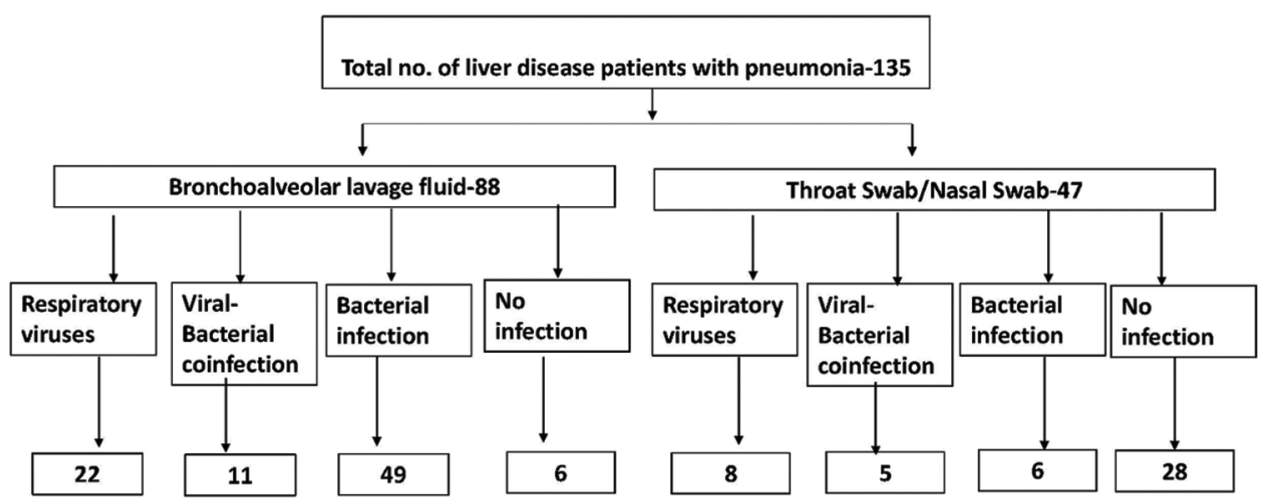

Figure 1: Work flow and algorithm in respiratory viruses testing in liver disease patients

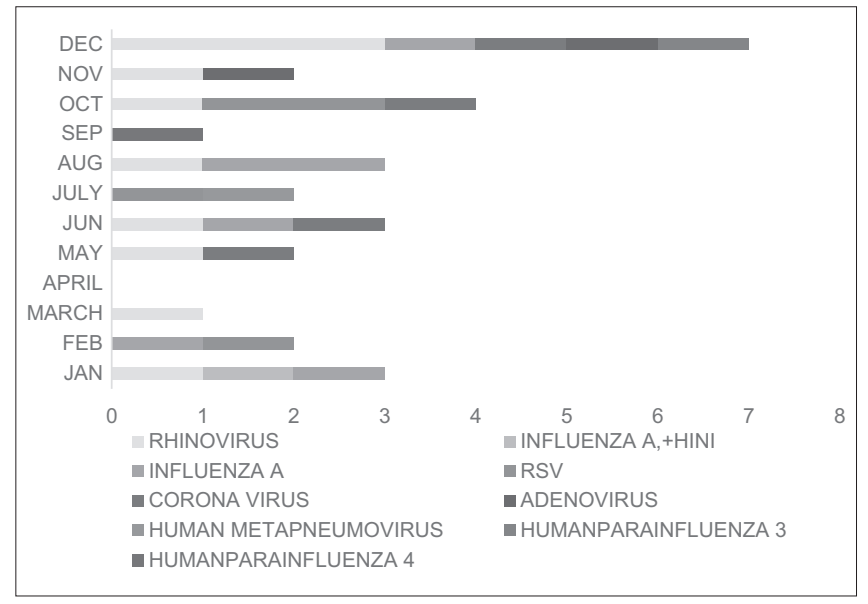

Figure 2: Monthly distribution and seasonality of respiratory viruses in liver disease patients with cirrhosis

bacterial pneumonia.; hence, a high index of suspicion is necessary for this infection. None of the previously done studies have shown the spectrum of different RVs in liver disease patients. Only a few studies done in our center have shown the prevalence of influenza virus and its impact on the clinical outcome of cirrhotic patients. ${ }^{[7,8,14]}$ The current study has found that respiratory viral infections other than influenza virus infection are also an important etiology of pneumonia in liver disease patients with cirrhosis admitted in CCUs. Transmission dynamics and seasonal distribution of RVs are key importance in understanding and limiting burden of morbidity and mortality of pneumonia patients in CCUs. ${ }^{[15]}$ In the current study, no clear seasonality is seen for human RhV. Flu A virus and RSV were mainly present in winter months. This finding can inform the timing of Flu A and RSV vaccination and the judicious use of antibiotics in cirrhotic patients admitted in CCUs. Mixed viral and bacterial infections are widely described in pneumonia patients in CCUs; however, the presence of these coinfections on the cirrhotic patients' clinical outcome remains poorly studied. ${ }^{[16]}$ Various studies suggest that viral and bacterial coinfections lead to a higher severity ongoing disease, especially in patients with chronic
Table 4: Distribution of respiratory pathogens and their mode of acquisition in patients

\begin{tabular}{|c|c|c|c|c|}
\hline Identified pathogens & Total $(n=135)$ & $\operatorname{CAP}(n=49)$ & $\operatorname{HAP}(n=86)$ & $P$ \\
\hline Isolated viral etiology & 30 & 13 & 17 & 0.47 \\
\hline RhV & 9 & 3 & 6 & 0.85 \\
\hline Flu A & 5 & 4 & 1 & 0.85 \\
\hline $\mathrm{HCOV}$ & 3 & 0 & 3 & 0.19 \\
\hline RSV & 3 & 0 & 3 & 0.19 \\
\hline HPIV & 2 & 1 & 1 & 0.69 \\
\hline HAdV + RhV & 2 & 1 & 1 & 0.69 \\
\hline HMPV & 1 & 1 & 0 & 0.18 \\
\hline HAdV & 1 & 1 & 0 & 0.18 \\
\hline HAdV + HPIV & 1 & 0 & 1 & 0.45 \\
\hline $\mathrm{HCOV}+\mathrm{RSV}$ & 1 & 0 & 1 & 0.45 \\
\hline HPIV + HAdV & 1 & 1 & 0 & 0.18 \\
\hline Flu A H1N1 (pdm 09) & 1 & 1 & 0 & 0.45 \\
\hline $\begin{array}{l}\text { Isolated-bacterial } \\
\text { etiology }\end{array}$ & 54 & 22 & 32 & 0.57 \\
\hline $\begin{array}{l}\text { Klebsiella } \\
\text { pneumoniae }\end{array}$ & 39 & 4 & 35 & 0.009 \\
\hline $\begin{array}{l}\text { Staphylococcus } \\
\text { aureus }\end{array}$ & 12 & 1 & 11 & 0.05 \\
\hline $\begin{array}{l}\text { Streptococcus } \\
\text { pneumoniae }\end{array}$ & 1 & 1 & 0 & 0.45 \\
\hline $\begin{array}{l}\text { Legionella } \\
\text { pneumophila }\end{array}$ & 1 & 1 & 0 & 0.45 \\
\hline Moraxella catarrhalis & 1 & 0 & 1 & 0.45 \\
\hline $\begin{array}{l}\text { Combined bacterial } \\
\text { and viral coinfections }\end{array}$ & 16 & 5 & 11 & 0.69 \\
\hline
\end{tabular}

disease. ${ }^{[16,17]}$ We did not find any significant correlation in mortality and median length of stay in CCUs in patients with only RV infection and viral-bacterial confection which is not in concordance of previous done studies. ${ }^{[18]}$

Our study had some limitations. First of all, our study was a single-center cohort and done in a small duration period. Considering small number of patients, our observations should be confirmed in larger sample size with more detailed subgroup in future study. Second, 
our study excluded cirrhotic patients with cancer and immunosuppression. Therefore, exclusions may result in statistic bias and inexact conclusion. Nevertheless, our investigation provided the first comprehensive study of the prevalence of RVs and its epidemiology in cirrhotic patients with pneumonia in CCUs. With the high morbidity and mortality rates associated with RV infections and the lack of directed antiviral therapy for most of these infections, prevention remains the mainstay for reducing their incidence and controlling transmission of RVs, especially in CCUs settings.

\section{Conclusion}

RVs may contribute to significant cause of pneumonia in cirrhotic patients. Therefore, there should be a high index of suspicion, and early diagnosis by rapid molecular test for RVs should be instituted in cirrhotic patients with pneumonia in CCUs.

\section{Acknowledgment}

We would like to thank all the innocent patients for agreeing in the study and for donating their clinical samples. We feel privileged to offer the deepest sense of gratitude and respect to our teacher, Dr. SK Sarin, Director of ILBS, for his invaluable guidance, supervision, and blessings, without which these works would not have seen the light of the day.

\section{Financial support and sponsorship \\ Nil.}

\section{Conflicts of interest}

There are no conflicts of interest.

\section{References}

1. Xu L, Ying S, Hu J, Wang Y, Yang M, Ge T, et al. Pneumonia in patients with cirrhosis: Risk factors associated with mortality and predictive value of prognostic models. Respir Res 2018;19:242.

2. Viasus D, Garcia-Vidal C, Castellote J, Adamuz J, Verdaguer R, Dorca J, et al. Community-acquired pneumonia in patients with liver cirrhosis: Clinical features, outcomes, and usefulness of severity scores. Medicine (Baltimore) 2011;90:110-8.

3. Hung TH, Tseng CW, Hsieh YH, Tseng KC, Tsai CC, Tsai CC. High mortality of pneumonia in cirrhotic patients with ascites.
BMC Gastroenterol 2013;13:25.

4. Jalan R, Fernandez J, Wiest R, Schnabl B, Moreau R, Angeli P, et al. Bacterial infections in cirrhosis: A position statement based on the EASL special conference 2013. J Hepatol 2014;60:1310-24.

5. Bajaj JS, O’Leary JG, Wong F, Reddy KR, Kamath PS. Bacterial infections in end-stage liver disease: Current challenges and future directions. Gut 2012;61:1219-25.

6. Preveden T. Bacterial infections in patients with liver cirrhosis. Med Pregl 2015;68:187-91.

7. Bajpai V, Gupta E, Kundu N, Kumar S, Maiwal R. Influenza A/ H1N1pdm 09 infection in liver disease patients requiring ICU care. Indian J Health Sci Care 2018;5:109.

8. Premkumar M, Devurgowda D, Dudha S, Maiwall R, Bihari C, Grover S, et al. A/H1N1/09 influenza is associated with high mortality in liver cirrhosis. J Clin Exp Hepatol 2019;9:162-70.

9. Marzano A, Marengo A, Ruggiero T, Allice T, Sanna C, Alessandria $\mathrm{C}$, et al. Clinical impact of $\mathrm{A} / \mathrm{H} 1 / \mathrm{N} 1 / 09$ influenza in patients with cirrhosis: Experience from a nosocomial cluster of infection. J Med Virol 2013;85:1-7.

10. Kalil AC, Metersky ML, Klompas M, Muscedere J, Sweeney DA, Palmer LB, et al. Management of adults with hospital-acquired and ventilator-associated pneumonia: 2016 clinical practice guidelines by the infectious diseases society of America and the American thoracic society. Clin Infect Dis 2016;63:e61-e111.

11. Hakki M, Strasfeld LM, Townes JM. Predictive value of testing nasopharyngeal samples for respiratory viruses in the setting of lower respiratory tract disease. J Clin Microbiol 2014;52:4020-2.

12. Kim ES, Park KU, Lee SH, Lee YJ, Park JS, Cho YJ, et al. Comparison of viral infection in healthcare-associated pneumonia (HCAP) and community-acquired pneumonia (CAP). PLoS One 2018;13:e0192893.

13. Wiemken T, Peyrani P, Bryant K, Kelley RR, Summersgill J, Arnold $\mathrm{F}$, et al. Incidence of respiratory viruses in patients with community-acquired pneumonia admitted to the intensive care unit: Results from the severe influenza pneumonia surveillance (SIPS) project. Eur J Clin Microbiol Infect Dis 2013;32:705-10.

14. Bal CK, Bhatia V, Kumar S, Saini D, Khillan V, Gupta E, et al. Influenza A/H1/N1/09 infection in patients with cirrhosis has a poor outcome: A case series. Indian J Gastroenterol 2014;33:178-82.

15. Althouse BM, Flasche S, Minh LN, Thiem VD, Hashizume M, Ariyoshi $\mathrm{K}$, et al. Seasonality of respiratory viruses causing hospitalizations for acute respiratory infections in children in Nha Trang, Vietnam. Int J Infect Dis 2018;75:18-25.

16. Hoffmann J, Machado D, Terrier O, Pouzol S, Messaoudi M, Basualdo $W$, et al. Viral and bacterial co-infection in severe pneumonia triggers innate immune responses and specifically enhances IP-10: A translational study. Sci Rep 2016;6:38532.

17. Bellinghausen C, Rohde GG, Savelkoul PH, Wouters EF, Stassen FR. Viral-bacterial interactions in the respiratory tract. J Gen Virol 2016;97:3089-102.

18. Morris DE, Cleary DW, Clarke SC. Secondary bacterial infections associated with influenza pandemics. Front Microbiol 2017;8:1041. 